Ks. Wojciech Góralski

Ius Matrimoniale

$26(2015) \mathrm{nr} 2$

\title{
Wpływ koncepcji małżeństwa na rozumienie zdolności konsensualnej w okresie poprzedzającym promulgację KPK z 1983 r.
}

W kan. 1095, nn. 1-3 KPK ustawodawca deklaruje brak zdolności konsensualnej do zawarcia małżeństwa w następujących przypadkach: 1) braku wystarczającego używania rozumu; 2) poważnego braku rozeznania oceniającego co do istotnych praw i obowiązków małżeńskich; 3) niezdolności do podjęcia istotnych obowiązków małżeńskich z przyczyn natury psychicznej.

Mając na uwadze rolę zgody małżeńskiej w powstawaniu małżeństwa oraz wymienione formy niezdolności konsensualnej można pytać, jaką „moc” i jakie możliwości zgody małżeńskiej są niezbędne, by można było mówić o zdolności konsensualnej do zawarcia małżeństwa ${ }^{1}$. Chodzi więc o bliższe określenie relacji zachodzącej między zgodą małżeńską a zdolnością konsensualną.

Pytanie o zdolność konsensualną, a ściśle o jej minimum, żywo przewijało się w doktrynie kanonicznego prawa małżeńskiego w okresie poprzedzającym promulgację KPK z 1983 roku. W pytaniu tym nie chodzi jednak o zastosowanie orzecznicze powołanego wyżej kanonu, lecz o odpowiedź o charakterze pozytywnym, dotyczącym owego minimum zdolności, o której mowa.

1 Zob. G. Versaldi, L'uomo debole e la capicità per autodonarsi: quale capacità per il matrimonio?, w: H. Franceschi, M. A. Ortiz (red.), Verità del consenso e capacità di donazione. Temi di diritto matrimoniale e processuale canonico, Roma 2009, s. 148. 
Dla określenia, kto jest zdolny do zawarcia małżeństwa, kryterium fundamentalnym i nieodzownym jest właściwe rozumienie samej rzeczywistości małżeńskiej, ujęte w sposób wyraźny lub implicite. Można powiedzieć, że jej analiza prowadzi do odpowiedzi na pytanie o rozumienie zdolności do podjęcia aktu zgody małżeńskiej, inaczej o zdolność konsensualną.

Gdy chodzi o wizję zdolności konsensualnej, ściśle związaną z postrzeganiem małżeństwa i jego istoty, to we wspomnianym okresie na szczególną uwagę zasługuje doktryna wybitnego współczesnego kanonisty i filozofa hiszpańskiego Javiera Hervady, b. profesora Universytetu Navarra w Pamplonie. Jak zauważa C. J. Erràzuriz ${ }^{2}$, jej zasadność można ostrzej dostrzec na tle innych teorii, których znaczącymi przedstawicielami (reprezentującymi dwie odmienne, choć mające wiele wspólnego opinie) są m.in. P. Gasparri, twórca KPK z 1917 roku, oraz zmarły w 1998 roku J. R. Keating, biskup amerykański (diecezji Arlington), autor prekursorskiego dzieła The Bering of Mental Impairment on the Validity of Marriage (Romae 1964).

\section{Teorie P. Gasparriego i J. R. Keatinga}

Według P. Gasparriego, który zwracał uwagę na małżeństwo in fieri, małżeństwo in facto esse jest samym kontraktem, który został zawarty, i który trwa wraz ze zgodą małżeńską oraz prawami i obowiązkami małżeńskimi, które zostały zaciągnięte ${ }^{3}$. Konsekwentnie, małżeństwo jawi mu się w swojej istocie jako prawdziwy kontrakt dwustronny, jakkolwiek należący do porządku o wiele wyższego, przede wszystkim pomiędzy ochrzczonymi, ponieważ jest prawomocną zgodą dwojga osób, które układają się co do tego samego przedmiotu, wprowadzając obowiązek sprawiedliwości wymiennej

2 C. J. Erràzuriz, La capacità matrimoniale vista alla luce dell'essenza del matrimonio, Ius Ecclesiae 14 (2002), s. 627.

3 P. Gasparri, Tractatus canonicus de matrimonio, wyd. 2, Città del Vaticano 1932, s. 12. 
dla każdej ze stron wykonywania lub zaniechania czegoś ${ }^{4}$. Znamienne jest uznanie przez kanonistę włoskiego ius in corpus jako przedmiotu zgody małżeńskiej ${ }^{5}$, co też zostało przyjęte w kan. 1081 \$ 2 KPK z 1917 roku.

O zdolności konsensualnej Gasparri traktuje w części swojego dzieła Tractatus canonicus de matrimonio poświęconej brakowi należytego rozeznania. Uważa, że w odniesieniu do każdej umowy, a w szczególności gdy chodzi o powzięcie zgody na zawarcie umowy małżeńskiej, konieczne jest używanie rozumu, które zazwyczaj osiąga się po ukończeniu siedmiu lat. Dodaje jednocześnie, że do powzięcia zgody małżeńskiej nie wystarczy zwykłe używanie rozumu, lecz wymaga się ponadto rozeznania, czyli dojrzałości sądu proporcjonalnej do kontraktu - w taki sposób, by kontrahent mógł zrozumieć naturę i moc kontraktu. Dlatego też, precyzuje, aby małżeństwo było ważne na mocy samego prawa naturalnego, obydwie strony powinny cieszyć się takim używaniem rozumu, które pozwala im rozumieć wystarczająco, czym jest małżeństwo i jego istotne przymioty, tj. że małżeństwo polega na dozgonnym i wyłącznym prawie w stosunku do ciała w porządku aktów przez się zdolnych do zrodzenia potomstwa, stosownie do kan. $1081 \S 2 \mathrm{KPK}^{6}$.

Broniona przez Gasparriego koncepcja małżeństwa naturalnego, ujętego tak, jak je ukazuje Pismo Święte, rzutowała na sposób rozumienia zdolności konsensualnej. W koncepcji tej małżeństwo jest kontraktem, z którego wypływają stosunki sprawiedliwości wymiennej pomiędzy małżonkami. Wizja ta zdominowała perspektywę tego

${ }^{4}$, ,...] matrimonium est vere consensus bilateralis, licet ordinis longe superioris praesertim inter baptisatos, cum sit legitimus duorum in idem placitum, obligationem inducens in utraque parte ex iustitia commutativa aliquid praestandi vel omittendi". - Tamże, s. 14.

5 Zob. tamże, s. 15-18.

6 „Proinde ut matrimonium ipso naturae iure valeat, utraque pars usu rationis ita pollere debet, ut quid sit matrimonium eiusdemque essentiales proprietates satis intellegere valeat, idest matrimonium consistere in iure perpetuo et exclusivo in corpus in ordine ad actus per se aptos ad prolis generationem [ podkr. - W.G.] (can. $1081 \S 2 ”$. - Tamże, s. 12. 
kanonisty do tego stopnia, że małżeństwo in facto esse jawi mu się jako trwanie owego kontraktu w czasie. Można powiedzieć, że optyka, w której eksponuje się małżeństwo in fieri, wciąż głęboko warunkowała małżeński system kanoniczny?

Naturalną konsekwencją przyjęcia tego rodzaju wizji małżeństwa przez zasłużonego kanonistę było określenie zdolności konsensualnej jako zdolności do zawarcia kontraktu. Ten ostatni powinno się znać w jego specyfice, a taka znajomość jest związana z normalnym rozwojem osoby. Mimo to jednak Gasparriemu chodzi o znajomość o charakterze teoretycznym, strona praktyczna natomiast sprowadza się do zdolności seksualnej i do minimum wieku określonego w KPK. Brak niezbędnego rozeznania oceniającego postrzega się tutaj w kategoriach ignorancji, braku znajomości tego, czym jest małżeństwo ujęte abstrakcyjnie. Dychotomia między zdolnością konsensualną rozumianą w sposób intelektualistyczny i zdolnością praktyczną, sprowadzoną do zdolności seksualnej, pochodzi ze sposobu pojmowania małżeństwa i uwydatnia jej ograniczenia.

W rzeczywistości idea małżeństwa (jako trwająca zgoda małżeńska) prezentowana przez wymienionego autora pozostaje w ścisłej relacji do incapacitas. Aby mianowicie zgoda była wolna, niezbędna jest wystarczająca znajomość małżeństwa; wydaje się jednak, że chodzi o znajomość podobną do tej, jaka wymagana jest do podjęcia kontraktu majątkowego: w tym znaczeniu, że nie jest postrzegana jako znajomość praktyczna, która wpływa bezpośrednio na przedmiot kontraktu' ${ }^{8}$ Tak więc idea małżeństwa in facto esse, a więc rozumianego jako relacja ze współmałżonkiem, obca jest doktrynie P. Gasparriego.

Gdy chodzi z kolei o próbę „wprowadzenia” małżeństwa in facto esse w zakres zdolności konsensualnej, to na uwagę zasługuje myśl

7 C. J. Erràzuriz, La capacità matrimoniale..., art. cyt., s. 629.

8 Tamże; Zob. także N. Álvarez De Las Asturias, La capacità consensuale per sposarsi nella storia del diritto canonico, w: H. Franceschi, M. OrTiz (red.), Discrezione di giudizio e capacità di assumere: la formulazione del can. 1095, Milano 2013, s. 120. 
J. R. Keatinga, który w 1962 roku opublikował artykuł ${ }^{9}$, w którym zaprezentował najbardziej jasne i spójne - spośród występujących $\mathrm{w}$ tym okresie, tak w doktrynie, jak i w orzecznictwie - ujęcie niezdolności konsensualnej.

Ówczesny doktorant na Wydziale Prawa Kanonicznego Papieskiego Uniwersytetu Gregoriańskiego, na 21 lat przed promulgowaniem przez Jana Pawła II nowego KPK postawił problem: czy amentia, który to termin powszechnie funkcjonował w obiegu prawnym (co obecnie odpowiadałoby pojęciu anomalii psychicznych) stanowi wadę zgody małżeńskiej czy raczej przeszkodę rozrywającą?

Zwracając uwagę na to, że struktura dowodzenia w obu przypadkach jest bardzo różna, Keating zaproponował rozróżnienie, które wykraczało poza kwestię dowodzenia. Stwierdził mianowicie, że jeśli w schemacie prawnym przyczyn nieważności małżeństwa amentia jest uważana za wadę zgody małżeńskiej, to kierunek dowodzenia będzie zmierzał do momentu, w którym została ona wyrażona. Stan umysłowy osoby pozostaje w sprzeczności wyłącznie w relacji do małżeństwa in fieri, a więc w relacji do jej aktualnej zdolności do "uruchomienia” funkcjonowania wszystkich elementów poznawczych i wolitywnych koniecznych do powzięcia pełnego aktu konsensu, aktu istniejącego (actus existens), kwalifikowanego aktu ludzkiego, który - sam z siebie (per se) byłby wystarczający dla zrodzenia węzła małżeńskiego ${ }^{10}$. Jeśli natomiast - jest to druga możliwa koncepcja, zaproponowana właśnie przez Keatinga - choroba umysłowa będzie traktowana jako przeszkoda rozrywająca, to naturalna integralność aktu zgody małżeńskiej nie będzie kryterium określającym ważność danego małżeństwa. Przypadek nie będzie więc dotyczył małżeństwa in fieri, lecz małżeństwa in facto esse. Stan umysłowy będzie przyczyną nieważności małżeństwa, jednak niekoniecznie dlatego, że stan ten uczynił osobę niezdolną do powzięcia aktu zgody małżeńskiej podczas zawierania małżeństwa, lecz dlatego, że czyni osobę

9 J. R. Keating, The „Caput Nullitatis” in Insanity Cases, The Jurist 22 (1962), s. 391-411.

10 Tamże, s. 393. 
fundamentalnie niezdolną do stanu małżeńskiego [podkr. w tekście oryginalnym - W.G.]"11.

W swojej propozycji kanonista amerykański snuje analogię w stosunku do przeszkody impotencji, odnosi się szczególnie do schorzeń psychoseksualnych (homoseksualizm i nimfomania) oraz przywołuje zasadę ad impossibile nemo tenetur ${ }^{12}$. Chodziłoby więc o przeszkodę impotencji moralnej.

Jakkolwiek do KPK z 1983 roku nie została wprowadzona nowa przeszkoda rozrywająca, to jednak do kan. 1095 (jako n. 3) została wpisana niezdolność do podjęcia istotnych obowiązków małżeńskich z przyczyn natury psychicznej. Powszechna interpretacja tej normy prawnej, opierając się na tym samym rozróżnieniu, które poczynił Keating, tytuł ten uznaje za autonomiczny w stosunku do poważnego braku rozeznania oceniającego co do istotnych praw i obowiązków małżeńskich wzajemnie przekazywanych i przyjmowanych (n. 2 powołanego kanonu). Jak zauważa C. J. Errázuriz, przyjmuje się w ten sposób jądro pojęciowe tezy kanonisty amerykańskiego, według której byłoby możliwe, by akt konsensu małżeńskiego, nieskażony psychologicznie, w którym tkwi konieczne rozeznanie oceniające, nie spowodował zaistnienia małżeństwa z powodu braku zdolności do podjęcia istotnych obowiązków małżeńskich, który to brak nie naruszałby natomiast zdolności do powzięcia poprawnego aktu zgody małżeńskiej ${ }^{13}$.

11 Tamże, s. 394-395.

12 Tamże, s. 395-396.

13 C. J. Erràzuriz, La capacità matrimoniale..., art. cyt., s. 631; Wbrew jednak stanowisku Keatinga, wymieniony kanonista hiszpański sądzi, iż w oparciu o samo pomieszczenie kan. 1095 KPK w obszarze zgody małżeńskiej, a także o jego dosłowne odniesienie do tejże zgody, jest możliwe, a nawet konieczne interpretowanie różnych numerów tegoż kanonu w inny sposób, jako trzech aspektów czy wymiarów tego samego aktu zgody małżeńskiej, z potwierdzeniem ich autonomii. W tym sensie n. 3 byłby wyjaśnieniem charakteru istotowo praktycznego zgody małżeńskiej. Takie wyjaśnienie byłoby konieczne, ponieważ niezależnie od rozwoju orzecznictwa i doktryny, także dzisiaj rozeznanie oceniające jest rozumiane w sposób raczej teoretyczny, i z trudnością zauważa się jego brak, choćby w przypadkach związanych z chorobami psychoseksualnymi. - Zob. tamże, s. 631-632. 
W twierdzeniach Keatinga nietrudno dostrzec relację miedzy pojęciem zdolności a ideą małżeństwa. Autor ten usiłuje zintegrować postrzeganie małżeństwa in fieri, obecnego w analizie ważności konsensu małżeńskiego, z oceną małżeństwa in facto esse. Zdolność małżeńska nie byłaby jedynie zdolnością do aktu, jakim jest zgoda małżeńska, lecz również zdolnością do stanu (życia w małżeństwie).

Teoria Keatinga, według której zdolność do zawarcia małżeństwa mierzy się funkcją małżeństwa in facto esse, jawi się jako trudna do przyjęcia. Małżeństwo in facto esse rozumie się często jako życie małżeńskie (communio vitae), owo trwanie w czasie wspólnoty raz ustanowionej, owo istnienie pary małżeńskiej, w którym ujawnia się niezdolność z powodu choroby umysłowej, jak to przedstawia Keating. W ten sposób małżeństwo zostaje „rozerwane” na dwie rzeczywistości: akt zgody małżeńskiej i życie małżeńskie, a capacitas jest mierzona w relacji do obu tych rzeczywistości ${ }^{14}$. Zresztą sam termin „małżeństwo” doznaje dość głębokiej erozji w kulturze zachodniej: gdy stwierdza się, że małżeństwo jest nieudane, pozostaje czymś oczywistym, że chodzi o wspólnotę małżonków, a nie o węzeł małżeński ${ }^{15}$.

Niezależnie od tego, czy za przedmiot zgody małżeńskiej uzna się ius in corpus czy communio vitae, w jednym i w drugim przypadku przyjmuje się, że zdolność konsensualną „mierzy się” w relacji tak do aktu zgody małżeńskiej, jak i do życia małżeńskiego. Powoduje to w konsekwencji przyjęcie istnienia dwóch rodzajów niezdolności: jedna dotyczy aktu zgody małżeńskiej, druga zaś życia małżeńskiego, obejmująca niemożność dopełnienia małżeństwa i wypełnienia obowiązków małżeńskich. Odnoszenie zdolności małżeńskiej do życia małżeńskiego C. J. Errázuriz uważa za wielki błąd, przede wszystkim z uwagi na bardzo zwyczajny motyw: życia małżeńskiego nie należy identyfikować $\mathrm{z}$ małżeństwem ${ }^{16}$.

Zarówno więc doktryna P. Gasparriego, jak i J. R. Keatinga nie mogą właściwie wskazywać niezdolności konsensualnej. To zgoda

\footnotetext{
14 Tamże, s. 632.

15 Tamże, s. 632-633.

16 Tamże, s. 632.
} 
małżeńska, nie zaś życie małżeńskie, powinna być witalna, a więc istnieć w stopniu umożliwiającym realizację jedności małżeńskiej, $\mathrm{w}$ przeciwnym wypadku staje się zwykłym pragnieniem ${ }^{17}$.

Wydaje się, że zarówno w poglądach P. Gasparriego, jak i J. R. Keatinga można dopatrzeć się błędu natury antropologicznej: ani rozum ani ciało ani psychika ludzka nie może być sama przyczyną małżeństwa, a więc także jego nieistnienia, jest nią bowiem osoba, która znajduje się w stanie posiadania w pewnym sensie własnego stanu seksualności oraz dania go za pomocą zgody małżeńskiej. Niezdolność należy więc odnieść do zgody małżeńskiej, jako osobowego aktu, w którym integralnie łączą się trzy pierwiastki: cielesny, psychiczny i duchowy. Zwrócił na to uwagę Jan Paweł II w przemówieniu do Roty Rzymskiej z 1988 roku. Odnosząc się do dyspozycji kan. 1095 KPK wskazał na potrzebę wyjścia od analizy antropologicznej konsensu małżeńskiego ${ }^{18}$. Jeśli zgoda małżeńska pochodzi od dwóch aktów odrębnych osób (mężczyzny i kobiety) $\mathrm{z}$ tą samą intencjonalnością, to powinno się zbadać, czy istnieje lub nie zdolność osób do posiadania owej intencjonalności. W przeciwnym wypadku powstaje ryzyko mylenia prawdziwej niezdolności z trudnością, przed czym przestrzegał Jan Paweł II w swojej alokucji do Roty Rzymskiej z 1987 roku $^{19}$. Jeśli dana osoba z uwagi na brak rozeznania, impotencję lub patologię psychiczną nie jest w stanie

\footnotetext{
17 Zob. H. FrancESCHI, L'incapacità relativa esplicita ed implicita, w: H. FrANCESCHI, J. Llobell, M.A. Ortiz (red.), La nullità del matrimonio: temi processuali e sostantivi in occasione della „Dignitas connubii”, Roma 2005, s. 359; G. H. VoN Wright, Freedom and Determination, Helsinki 1980, s. 103; C. J. Errázuriz, Sul rapporto tra il consenso e il matrimonio: il consenso quale atto umano che assume l'altra persona nella sua dimensione coniugale naturale, w: H. Franceschi, M. A. ORTIZ (red.), Verità nel consenso e capacità di donazione. Temi di diritto matrimoniale e processuale canonico, Roma 2009, s. 58-59.

18 Zob. Giovanni Paolo II, Discorso alla Rota Romana, 25 I 1988, AAS 80 (1988), s. 1182.

19 Giovanni Paolo II, Discorso alla Rota Romana, 5 II 1987, AAS 79 (1987), s. 1457.
} 
powziąć takiego aktu, tj. nie może chcieć być mężem czy żoną, nie istnieje zgoda małżeńska ${ }^{20}$.

\section{Teoria J. Hervady}

Zdolność konsensualną można poprawnie zrozumieć na gruncie teorii J. Hervady, na co zwrócił uwagę m.in. C. J. Erràzuriz ${ }^{21}$. Wizja małżeństwa i jego istoty oraz zgody małżeńskiej u tego pierwszego pozwoliły mu ukazać capacitas we właściwym kontekście: w relacji do istoty małżeństwa. Choć swoje poglądy prezentował na krótko przed promulgacją KPK z 1983 roku, to jednak jego refleksje mają fundamentalne znaczenie dla interpretacji kan. 1095, nn. 1-3 KPK.

Problem zdolności konsensualnej, ściśle związany z dziedziną zgody małżeńskiej, J. Hervada uważa za niezwykle znaczący, tym bardziej, że współcześnie znane teorie usiłują znacznie poszerzyć katalog tytułów nieważności małżeństwa pochodzących z samego prawa naturalnego, mających swoje źródło w anomaliach psychicznych. Jego zdaniem, capacitas - jako wystarczająca normalność psychiczna - była dotąd rozpatrywana na gruncie pewnych, dość prostych zasad teoretycznych, nawet gdy z czasem praktyka nastręczała poważne trudności.

Wymieniony kanonista przywiązuje najpierw baczną uwagę do aktualności capacitas podkreślając, że powinna ona być odnoszona do aktu zawierania małżeństwa, wszak chodzi o zdolność do powzięcia tego właśnie aktu, nie zaś o zdolność ad statum coniugalem. W stosunku do tego stanu anomalię psychiczną uważa się jako wadę i przeszkodę dla jego normalnego i pomyślnego rozwoju, a ponadto jako wymóg w stosunku do małżonka zdrowego przystosowania się do stanu małżonka chorego, przy wzięciu pod uwagę powinności niesienia sobie przez małżonków wzajemnej pomocy i pełnienia

20 Zob. J. Hervada, Studi sull'essenza del matrimonio, Milano 2000, s. 302; A. Malo, Capacità consensuale di contrarre matrimonio in prospettiva antropologica, w: H. Franceschi, M. A. Ortiz (red.), Disrcezione di giudizio..., dz. cyt., s. 55. 21 C. J. Erràzuriz, La capacità matrimoniale..., art. cyt., s. 634-637. 
dzieł miłości małżeńskiej. Chodzi zatem o sytuację nieszczęśliwą dla obojga małżonków, nie zaś o sytuację niekompatybilną, wynikającą ze status coniugalis. Anomalia psychiczna jest jednak niezdolnością jedynie wówczas, gdy stoi na przeszkodzie do podjęcia ważnego aktu zawarcia małżeństwa ${ }^{22}$.

Analizując następnie wysuwane ówcześnie tytuły nieważności małżeństwa: niezdolność do podjęcia i wypełnienia obowiązków małżeńskich, niezdolność do nawiązania wspólnoty życia i miłości, niezdolność do nawiązania relacji międzyosobowych, niedojrzałość afektywną itp., Hervada wyróżnia tutaj dwie wskazywane w doktrynie grupy owych źródeł incapacitas. Pierwsza obejmowałaby anomalie osobowości, które „przeszkadzałyby” w wypełnianiu obowiązków małżeńskich, powodując w podmiocie niezdolność do panowania nad otrzymywanymi przeciwnymi impulsami i bodźcami. Tego rodzaju anomalie nie stanowiłyby tytułów nieważności różnych od niezdolności do powzięcia konsensu. Chcieć kogoś drugiego jako małżonka, co jest aktem konsensu, implikuje przyjęcie $\mathrm{z}$ uwagi na niego specjalnych obowiązków. Jeśli podobne anomalie rzeczywiście występują, dla Hervady jest czymś oczywistym, że czynią one osobę niezdolną do przyjęcia kogoś drugiego jako małżonka, ponieważ nie może mieć wówczas miejsca akt prawdziwego chcenia (voluntarium), a tylko zwykłe chcenie (volitum), chcenie nieskuteczne. Tymczasem zgoda małżeńska nie jest aktem pragnienia, nawet bardzo usilnego, nie jest chceniem nieskutecznym, lecz aktem woli (właśnie voluntarium), a więc chceniem skutecznym i operatywnym. W takim przypadku rozum nie jest zdolny do pokierowania wolą, ta zaś jest niezdolna do wypełnienia obowiązków, które się podejmuje. W drugiej grupie przyczyn niezdolności wymieniony autor sytuuje anomalie, które czyniąc podmiot niezdolnym do wspólnoty całego życia i do pełnej oraz dojrzałej integracji obojga małżonków, naruszałyby „w korzeniu” akt zgody małżeńskiej, czyniąc go nieważnym ${ }^{23}$.

22 J. Hervada, Studi sull'essenza del matrimonio, dz. cyt., s. 398-399;

C. J. ERRÀzURIz, La capacità matrimoniale..., art. cyt., s. 634.

${ }^{23}$ J. Hervada, Studi sull'essenza del matrimonio..., dz. cyt., s. 299-300. 
Odnosząc się do tego rodzaju stwierdzeń, wybitny kanonista hiszpański uznaje, że wysuwane przyczyny incapacitas traktowane w odniesieniu do jedności dwojga małżonków mogą powodować nieważność małżeństwa jedynie wówczas, gdy stają na przeszkodzie „jedności w naturach”, a konkretnie chodziłoby o te, które czyniłyby strony niezdolnymi do miłości małżeńskiej i które wpływałyby radykalnie na jedność osobowego „ja” obu stron. Autor stawia jednocześnie pytanie, czy istnieje taka niezdolność ${ }^{24}$.

W odpowiedzi J. Hervada stwierdza najpierw, że na pewno nie można mówić o niezdolności do pociągu uczuciowego ani do miłości biernej - tak sentymentalnej, jak i wolitywnej. Ani instynkt nie jest miłością, ani miłość małżeńska, mówiąc ściśle, nie jest miłością bierną. Miłość małżeńska jest istotowo miłością refleksyjną woli, tą miłością, którą klasycy określają mianem dilectio (decyzja woli). Mając to na uwadze, trzeba powiedzieć, że niezdolność w stosunku do miłości stałaby się niezdolnością w stosunku do dzieł miłości określonych przez cele małżeństwa (niezdolność do miłości małżeńskiej jest niczym innym, jak niezdolnością do realizacji celów małżeństwa).

${ }^{24}$ Według J. Hervady istotą małżeństwa in facto esse jest węzeł prawny będący „jednością w naturach” uprzednią w stosunku do jakiegokolwiek działania pary małżeńskiej jako takiej. Pogląd ten sytuuje się między dwiema koncepcjami ekstremalnymi: tradycyjną, dostrzegającą istotę małżeństwa w ius in corpus, a tą, która wskazuje tutaj na pewien personalizm w postaci communio vitae. W świetle takiego ujęcia małżeństwo nie polegałoby ani na jedności ciał (w przeciwieństwie do rzeczników ius in corpus) ani na działaniach podejmowanych przez małżonków wspólnie (w przeciwieństwie do zwolenników dostrzegania istoty małżeństwa w communio vitae). Hervada utrzymuje, że jedność natur powstaje poprzez węzeł małżeński udziału i wzajemnej komunikacji męskości i kobiecości - rozumianych jak całkowita zróżnicowana struktura duchowa i cielesna, na mocy której mężczyzna i kobieta czynią się wzajemnymi współposiadaczami. Przez owo współposiadanie oboje małżonkowie uczestniczą - prawnie, nie zaś ontologicznie (ponieważ nie byłoby to możliwe) - we władaniu, które każdy z nich ma przez fakt bycia osobą; czymś jasnym jest, że uczestnictwo to jest ograniczone do męskości i do kobiecości. Małżeństwo przed zaistnieniem: w jedności działania, życiu i miłości jest węzłem prawnym w istnieniu, jest jednością w naturach (mężczyzny i kobiety). - Tamże, s. 275; Zob. także A. Malo, Capacità consensuale..., art. cyt., s. 34. 
Wybitny kanonista uważa więc, że z jednej strony można by uznać, że niezdolność psychiczna jest tytułem nieważności zupełnie innym, z drugiej zaś mogłoby wynikać, iż istnieje niezdolność do wzajemnego wspierania się wskutek niewątpliwej niezdolności woli. Lecz taka wola, niezdolna do chcenia dzieł miłości małżeńskiej, wydaje się być w sposób konieczny wolą prawdziwie niezdolną do chcenia małżeństwa. Jeśli miłość małżeńską pojmuje się właściwie, jako dilectio, to każda możliwa niezdolność w stosunku do miłości sprowadza się do znanych figur niezdolności w stosunku do obowiązków małżeńskich, bez możliwości mówienia o autonomicznej figurze incapacitas ${ }^{25}$.

W dyskursie J. Hervady na szczególną uwagę zasługuje wskazanie istotnych momentów pozwalających właściwie rozumieć zdolność konsensualną. Tak więc primo, zdolność do powzięcia zgody małżeńskiej odnosi się do aktu, a nie do stanu (habitualnego), jest więc sytuacją chwilową, i dlatego odnosi się do stanu kontrahenta w momencie zawieranie przezeń małżeństwa. Każdy brak w stosunku do przyszłego rozwoju życia małżeńskiego albo sprowadza się do braku istniejącego w danym momencie (zawierania związku) albo nie jest niezdolnością. Niezdolność w odniesieniu do małżeństwa i, a contrario, zdolność do zawarcia go powinna być aktualna. Secundo, zdolność do powzięcia konsensu winna być odniesiona do aktu voluntarium, którym jest tenże konsens: do jego natury oraz do jego przedmiotu i jego wymogów. Wszystko to, co „wymyka się” spod aktu voluntarium (powzięcie konsensu), może być wzięte pod uwagę na drodze prawa pozytywnego, lecz nie jest niezdolnością prawa naturalnego. Tertio, zdolność prawa naturalnego nie rozciąga się na zdolność do osiągnięcia pełnej i doskonałej integracji małżonków, tzn. nie rozciąga się na to, co dotyczy rozwoju egzystencjalnego, który zależy od wolnych wyborów małżonków. Mówiąc inaczej, capacitas naturalis nie może odnosić się do historii, która nie jest kwestią zdolności, lecz wolności; nie może też odnosić się do uwarunkowań społecznych, które nie są o charakterze naturalnym, lecz kulturowym; odnosi się

25 J. HervadA, Studi sull'essenza del matrimonio..., dz. cyt., s. 301-302. 
wyłącznie do tego, co naturalne; wszystko inne powinno być dziełem prawa pozytywnego ${ }^{26}$.

Zdaniem Hervady, każdy akt świadomy i dobrowolny (voluntarium), jak wiadomo, w swojej jedności składa się dwóch elementów, które go konstytuują: poznawczego i wolitywnego. Chodzi w istocie o to, by chcieć, znając to, czego się chce. Inteligencja i wola, „wiedzieć” $\mathrm{i}$ „chcieć” są dwoma komponentami aktu voluntarium. W stosunku do zgody małżeńskiej znany autor ośmiela się - jak sam zaznacza - zaryzykować stwierdzeniem, iż spośród tych dwóch elementów wypada zarysować dokładnie ten pierwszy: element poznawczy - w aspekcie, który ma swoje znaczenie ${ }^{27}$.

Przypominając dwa sposoby używania rozumu: spekulatywny i praktyczny, autor zauważa, że - generalnie - gdy mówi się o elemencie poznawczym aktu konsensu małżeńskiego, akcentuje się wówczas moment spekulatywny, czyli zdolność do poznania natury małżeństwa. Tymczasem, jego zdaniem, jeśli prawdą jest, iż poznanie spekulatywne jest konieczne, to nie jest ono czymś decydującym; czymś decydującym jest tutaj sąd praktyczny (iudicium practicum), w którym tkwi czynnik poznawczy aktu zawarcia małżeństwa. W rezultacie akt voluntarium zawarcia małżeństwa odnosi się do rzeczywistości, która jest operatywna. Zawrzeć małżeństwo oznacza zobowiązać się do dzieła wspólnego, które nosi na sobie wymiar operatywno-praktyczny wspomnianej wyżej „jedności w naturach”. Elementem konstytutywnym więc nie jest tylko i zasadniczo poznanie spekulatywne, lecz przede wszystkim poznanie praktyczne. W każdym razie, zawrzeć małżeństwo nie jest zwykłym stwierdzeniem lub deklaracją, lecz jest działaniem, chceniem połączenia się z uwagi na cele. Wynika stąd, że rozum powinien wydawać sąd praktyczny, i że zdolność do powzięcia konsensu małżeńskiego jest pewnym rozeznaniem, zdolnością rozumu praktycznego, stąd też określenie: discretio iudicii. To, czego wymaga się od kontrahenta,

26 Tamże, s. 302.

27 Tamże. 
to by był wystarczająco zdolny do rozeznania, czyli by posiadał wystarczającą dojrzałość w zakresie rozumu praktycznego ${ }^{28}$.

Według Hervady, rozum praktyczny i rozum spekulatywny nie są, jak wiadomo, dwoma rozumami różnymi, lecz dwoma sposobami działania jednego i tego samego rozumu ludzkiego; różny może być tylko ich rozwój. Można więc dać przykład osób dorosłych, które, choć odznaczają się znacznym rozwojem rozumu spekulatywnego, przejawiają w o wiele mniejszym stopniu rozwój rozumu praktycznego; w ten sam sposób możliwe są zmiany psychiczne, które dotyczą bardziej rozumu praktycznego niż rozumu spekulatywnego. Dojrzałość wymagana do małżeństwa nie jest - konsekwentnie zwyczajną dojrzałością intelektywną rozumienia funkcjonujących w świecie idei i pojęć, lecz jest dojrzałością zastanawiania się i decydowania w odniesieniu do własnej przyszłości. Jest czymś oczywistym, że dla podjęcia ważnej decyzji zawarcia małżeństwa konieczna jest możność poznania, czym jest małżeństwo, lecz elementem konstytutywnym wystarczającego rozeznania oceniającego nie jest zdolność intelektywna (choć niewątpliwie jest konieczna), jest nią natomiast zdolność aktu imperium rozumu praktycznego, na ile jest zdolny do kierowania wolą (i afektywnością) oraz orientowania jej ku decyzji, która wiąże przyszłość osobową. W konsekwencji, wymagane używanie rozumu nie jest tylko używaniem rozumu spekulatywnego, choć wymaga się także i tego, lecz w szczególności jest używaniem rozumu praktycznego. Kwestią jest zatem zdolność zastanawiania się i decydowania ${ }^{29}$.

\footnotetext{
28 Tamże, s. 303-304; Zob. także J. Hervada, P. Lombardia, El Derecho del Pueblo de Dios, t, 3/1: Derecho matrimonial, Pamplona 1973, s. 474.

29 Zdaniem Hervady należy przyjąć, że anomalie woli są konsekwencją anomalii rozumu praktycznego. - J. HervadA, Studi sull'essenza del matrimonio..., dz. cyt., s. 304-305.
} 


\section{Uwagi końcowe}

Wysiłki doktryny i orzecznictwa czynione pod rządami KPK z 1917 roku w zakresie poszukiwania właściwego rozumienia zdolności konsensualnej do zawarcia małżeństwa nie straciły na wartości po promulgowaniu przez Jana Pawła II nowego KPK, w którym skodyfikowano trzy formy niezdolności konsensualnej (kan. 1095, nn. 1-2). Wszak także dzisiaj w interpretacji i stosowaniu tychże norm prawnych czymś istotnym pozostaje nadal znajomość tego, czym jest małżeństwo.

Historię usiłowań zmierzających do pozytywnego określenia zdolności do zawarcia małżeństwa można sprowadzić do historii poszukiwania kryteriów „miary”, z pomocą których można by wskazać minimum tejże zdolności konsensualnej; kryteria te zaś implikują odpowiednie punkty odniesienia. Wśród tych ostatnich można wyodrębnić te, które pochodzą niejako ab extrinseco, tj. ze stosowania porównań, oraz pochodzące $a b$ intrinseco, tzn. od osób samych nupturientów. Gdy chodzi o te pierwsze, to można się tu odnosić m.in. do zdolności bycia odpowiedzialnym moralnie za grzech ciężki, zdolności zawierania innych umów czy też zdolności do podejmowania innych stanów życia (np. zakonnego). Co się tyczy natomiast drugiego rodzaju odniesień, to pozostawia się tutaj wszelkie porównania i kieruje się uwagę bezpośrednio ku nupturientom: zarówno $\mathrm{w}$ aspekcie pozytywnym (poprzez wzięcie pod uwagę procesu dojrzewania osoby), jak i negatywnym (poprzez analizę anomalii, które mogą spowodować niezdolność).

Czymś znamiennym jest, że owe punkty odniesienia mogą być pożyteczne pod warunkiem, że wiadomo, czym jest małżeństwo. Do określenia bowiem, kto jest w stanie zawrzeć taki związek, kryterium fundamentalne i niezastąpione pochodzi ze zrozumienia samej rzeczywistości małżeńskiej.

Niewątpliwie wizję małżeństwa, na gruncie której można właściwie określić zdolność konsensualną, przekonująco nakreślił w swojej doktrynie J. Hervada. 


\title{
Influence of the concept of marriage on the understanding of consensual ability regarding the period preceding the CIC promulgation of 1983
}

\begin{abstract}
Summary
The question about the consensual ability, especially its minimum, has been visible in the doctrine of canonical marital law in the period preceding the CIC from 1983. To specify who is able to enter into marriage, the fundamental criterion is the proper understanding of the very marital reality.

Regarding the vision of consensual ability, related strictly to the perception of marriage and its very nature, in the considered period special attention needs to be paid to the doctrine of a prominent modern Spanish canonist and philosopher J. Hervada. Its legitimacy can be vividly seen against the background of other theories, whose main representatives, although presenting different opinions (although having a lot in common) are, inter alia, P. Gasparri and J. R. Keating.

Gasparri's concept of marriage is a contract (matrimonium in fieri), which is the fountain of the relationship of mutual justice between spouses. Keating, however, strives to integrate the perception of marriage in fieri with the marriage in facto esse. The marital ability would not only be the ability to the act of marital congruence, but also the ability to live in marriage.

According to Hervada, the essence of marriage in facto esse is the legal bond being "unity in natures" prior to any action of the married couple as such. The mentioned canonist attaches significant importance to the capacitas underlining that it should be referred to the act of entering into marriage, it is about the ability to undertake this act not about the ability ad statum coniugalem. He opines that the causes of incapacitas treated in reference to this unity of spouses may cause the invalidity of marriage only if they stand in the way of "unity in natures".
\end{abstract}

